\title{
studia
}

\section{Johanna Gottlieba Fichtego uzasadnienie wiary w moralny porządek świata}

Mimo wszelkich różnic, jakie dzielą filozofię Hegla, Schellinga i Fichtego na uwagę zasługuje łączący je fakt - pierwotne próby filozoficzne, w tym próby zastosowania rozstrzygnięć filozofii Kantowskiej, skoncentrowane były na problematyce teologicznej. W 1792 roku Schelling przedstawił łacińską rozprawę Antiquissimi de prima malorum origine philosophematis explicandi tentamen criticum - stanowiącą podsumowanie filozoficznych interpretacji mitu o upadku pierwszych ludzi - jako podstawę zaliczenia studiów teologicznych. W tym samym roku Hegel rozpoczął pracę nad manuskryptem zatytułowanym Volksreligion und Christentum ${ }^{1}$. Również w 1792 roku, dzięki osobistemu wstawiennictwu Kanta, ukazała się pierwsza rozprawa Fichtego zatytułowana Versuch einer Kritik aller Offenbarung.

Filozoficzno-religijne konsekwencje głównych dzieł Immanuela Kanta na ogół zwykło się oceniać przez pryzmat krytyki spekulatywnych dowodów na istnienie Boga. W tej pespektywie Kant jawi się jako agnostyk, który zaprzeczył tradycji sięgającej Arystotelesa, a kontynuowanej z powodzeniem

\footnotetext{
${ }^{1}$ W roku 1795 Hegel napisał rozprawkę Das Leben Jesu oraz rozpoczął pracę nad rozprawą zatytułowaną Die Positivität der christlichen Religion. W 1798 zredagował Der Geist des Christentums und sein Schicksal. Rozprawy te ukazały się drukiem dopiero po śmierci filozofa. Polskie wydanie: G.W.F. Hegel, Pisma wczesne z filozofii religii, przeł. G. Sowinski, Kraków 1999.
} 
głównie w obrębie systemów spekulatywnych późnej scholastyki, aż po XVII i XVIII wiek ${ }^{2}$. Nie ulega wątpliwości, że taki sposób interpretowania rezultatów Krytyki czystego rozumu utrwalił się między innymi za sprawą sugestywnych alegorii i porównań formułowanych w kręgu XIX-wiecznych filozofów i pisarzy - Hegla, Heinego czy Novalisa - gdzie chętnie przypisywano Kantowi radykalizm porównywalny z radykalizmem dyktatorów rewolucji francuskiej.

Krytyka teologii spekulatywnej, a właściwie pewnej wersji metafizyki uprawianej w XVIII wieku w kręgu filozofów odwołujących się do Leibniza (Wolffa, Baumgartena, Crusiusa i innych), była efektem podjętych przez Kanta nieudanych prób formułowania dowodów istnienia Boga, których ślady znajdujemy w przedkrytycznych rozprawach (Principiorum primorum cognitionis metaphysicae nova dilucidatio oraz Der einzig mögliche Beweisgrung zu einer Demonstration des Dasein Gottes). Fiasko dowodów nie narusza jednak pewności istnienia Boga, ponieważ prawda „Bóg jest” nie może się zachwiać - czytamy w pierwszym zdaniu Jedynej możliwej podstawy dowodu na istnienie Boga - nawet jeśli nie możemy jej wesprzeć za pomocą „głębokich badań metafizycznych"3. Na czym więc opierać się ma owa pewność? W pismach tych nie znajdziemy jeszcze odpowiedzi na to pytanie, jakiego udziela Krytyka czystego rozumu, a zwłaszcza Krytyka praktycznego rozumu. Znajdujemy w nich jednak przekonanie, że na rozumie teoretycznym nie musimy polegać jako na jedynym źródle naszej pewności w odniesieniu do tego, co nadzmysłowe. Ostatnie zdanie Jedynej możliwej podstawy dowodu na istnienie Boga brzmi: „Jest ze wszech miar koniecznym przekonać się o istnieniu Boga, ale nie aż tak znowu koniecznym, ażeby go dowodzić" ${ }^{2}$. Wraz z krytyką teologii pojawia się perspektywa zastosowania rozumu praktycznego, którą Kant podejmuje już od czasu publikacji Krytyki czystego rozumu. Niekiedy, również

\footnotetext{
${ }^{2}$ Interpretacja taka w naszym kraju była chyba podzielana głównie w środowisku katolickich krytyków modernizmu z początku XX wieku. Polemiki z filozofią Kanta prowadzili w tym duchu między innymi Michał Dębicki, Antoni Szlagowski, Stanisław Miłkowski czy Ignacy Charaszewski. Z obecnej perspektywy inaczej oceniamy formułowane wówczas sądy, które były głównie wynikiem poszukiwania przez Kościół katolicki odpowiedniego narzędzia filozoficznego uzasadnienia swej doktryny. Współczesne oceny filozofii Kanta, również powstające w środowisku katolickim, są łagodniejsze, choć respektują ustalony w rezultacie ówczesnych sporów punkt odniesienia - filozofię św. Tomasza z Akwinu.

${ }^{3}$ I. Kant, Jedyna możliwa podstawa dowodu na istnienie Boga, przeł. Translatorium Filozofii Niemieckiej IF UMK, Kęty 2004, s. 41.

${ }^{4}$ Tamże, s. 134.
} 
błędnie, jest ona traktowana jako alternatywna droga dowodzenia istnienia Boga, czym nigdy dla Kanta nie była.

Spróbujmy w tym kontekście postawić pytanie o rzekomy ateizm Kanta. Autor Krytyki czystego rozumu nie uważa, że kryterium ateizmu miałaby być niewiara w możliwość poznania istnienia Boga na drodze, jaką wskazuje teologia spekulatywna. Wyraźnie o tym świadczy treść wykładów poświęconych filozoficznej teorii religii:

Ateizm jest albo sceptyczny, gdy odrzuca wszelkie przekonania dotyczące istnienia Boga oraz wszelkie jego pewne poznania; bądź dogmatyczny, gdy zaprzecza istnieniu Boga w ogóle. Ateista sceptyczny może wyznawać jakąś religię; ponieważ nie dowodzi on niemożliwości istnienia Boga; a gdy tylko wierzę w możliwość Boga, wówczas może już mieć miejsce jakaś religia. Jest to jednak mizerny rezultat. Taki ateista jest bezbożnikiem [Ohngötter].

Ateista dogmatyczny jest bezbożnikiem [Gottesleugner], który istnienie Boga uznaje za nieuzasadnione. Ponieważ jednak rozum nie może nas w tej sprawie pouczyć ani też nigdy nie zdoła tak daleko wejrzeć w możliwość rzeczy, aby sprawić, żeby Bóg był również możliwy, to można wierzyć, że albo nie było żadnego ateizmu dogmatycznego, albo że formułowano go ze złośliwości serca, bądź też z powodu niezadowolenia ze swego losu. Wyznawanie takiego poglądu byłoby zatem największą głupotą.

Teizm krytyczny bądź moralny formułuje przekonanie [o istnieniu Boga] na podstawie rozumu praktycznego, uwzględniając przy tym ograniczenie rozumu spekulatywnego w tej kwestii. Po części przeciwstawia się sceptycznemu ateizmowi, po części zaś dogmatycznemu deizmowi. Nie usuwa przez to jednak ataku sceptycznego ateizmu, ponieważ nie sięga on w ogóle istnienia Boga, ale tylko jego spekulatywnych dowodów. Do takiego [wniosku] prowadzi krytyczne poznanie naszego rozumu. Dzięki moralnemu teizmowi jesteśmy wystarczająco zabezpieczeni przed sceptycznym ateizmem. Rozważamy tu bowiem Boga jako prawodawcę w królestwie moralności celów 5 .

Ateizm poznawczy (sceptyczny) nie wyklucza, zdaniem Kanta, teizmu moralnego. To umiarkowane stanowisko filozof znacznie bardziej zaostrzy w późniejszych pismach, w których ostatecznie dojdzie do przekonania, że

${ }^{5}$ Danziger Rationaltheologie, [w:] Kant's gesammelte Schriften, t. 27, Berlin 1972, s. 1246-1247 . 
wspomnianym na końcu Jedynej możliwej podstawy na istnienie Boga źródłem pewności o istnieniu Boga może być wyłącznie teizm moralny, a wszelkie formy wiary w Boga oparte na spekulacji uzna za bałwochwalstwo. W tym punkcie z pewnością zbiegają się przekonania Kanta oraz Fichtego, wyrażone w rozprawce O podstawie naszej wiary w boskie panowanie nad światem. Dalszych wniosków tej pracy - utożsamienia moralnego porządku z Bogiem nie dałoby się chyba utożsamić z żadną wypowiedzią Kanta zawartą na stronach opublikowanych przez niego pism. Nie znaczy to oczywiście, że nie jest ona zgodna $z$ duchem filozofii transcendentalnej. Bez trudu również możemy wskazać na szereg wypowiedzi filozofa zachowanych w Opus postumum, w których zdanie to sformułowano tak, jak uczynił to Fichte ${ }^{6}$.

Fichte, od czasu gdy w 1794 roku objął katedrę na uniwersytecie w Jenie, karierę naukową łączył z aktywnością polityczną oraz działalnością moralizatorską. W latach 1794-1795 ukazały się pierwsze prace objaśniające ideę Wissenschaftslehre, a równolegle z nimi rozprawy, które miały popularyzować jej ducha w szerszych kręgach, znacznie wykraczających poza wąskie grono uczonych i studentów ${ }^{7}$. Prowokacyjne zachowania Fichtego związane z wyznaczeniem pory wykładów niedzielnych oraz zaangażowanie w społeczne życie studenckie były niejednoznacznie oceniane ${ }^{8}$. Jest to również okres, w którym Fichte, przy współpracy z Friedrichem Immanuelem Niethammerem, rozpoczyna wydawanie „Philosophische Journal”, pisma, na łamach którego trzy lata później ukaże się rozprawka O podstawie naszej wiary w boskie panowanie nad światem.

Zredagowanie wspomnianej rozprawki zostało sprowokowane przez znanego Fichtemu, sympatyka jego filozofii, Friedricha Karla Forberga ${ }^{9}$. Arty-

${ }^{6}$ Szerzej na temat radykalizacji stanowiska Kanta zob. T. Kupś, Filozofia religii Immanuela Kata, Toruń 2008, s. 325 i n.

${ }^{7}$ Einige Vorlesungen über die Bestimmung des Gelehrten z 1794 roku - jedna z ważniejszych prac tego okresu - były przedmiotem analiz Józefa Kalasantego Szaniawskiego już na początku XIX wieku (rękopis Biblioteki im. Zielińskich w Płocku, sygn. 498). Mało reprezentatywny fragment pracy Szaniawskiego anonimowo ukazał się w 1803 roku na łamach „Nowego Pamiętnika Warszawskiego” z inicjatywy F.K. Dmowskiego. Por. T. Kozanecki, Płockie rękopisy Józefa Kalasantego Szaniawskiego, „Archiwum Historii Filozofii i Myśli Społecznej” 1961, t. 1.

${ }^{8}$ Por. Z. Kuderowicz, Fichte, Warszawa 1963, s. 19 i n.

${ }^{9}$ Por. W. Röhr, Nachwort des Herausgebers, [w:] Appellation an das Publikum... Dokumente zum Atheismusstreit um Fichte, Forberg, Niethammer. Jena 1798/99, hrsg. von Werner Röhr, Leipzig 1987; K.M. Kodalle, M. Ohst (red.), Fichtes Entlassung: der Atheismusstreit vor 200 Jahren, „Kritisches Journal der Philosophie” 1999, t. 4. 
kuł Forberga zatytułowany Entwicklung des Begriffs der Religion ${ }^{10}$ stanowił nawiązanie zarówno do wczesnej filozoficzno-religijnej rozprawy Fichtego (Versuch einer Kritik aller Offenbarung z 1792 roku), a pośrednio do Kantowskiej koncepcji religii rozumowej, przede wszystkim był jednak kontynuacją przyjętej wcześniej przez Forberga interpretacji religii w kategoriach skrajnie moralnych. Jednoznaczne przesłanie rozprawki - w myśl którego religia miałaby sprowadzać się wyłącznie do moralności, nie przypisując religii nic co do treści samoistnego - raziło Fichtego, który uznał za niezbędne wyrazić przy tej okazji własne stanowisko w tej sprawie. Fichte przewidywał nieprzychylne przyjęcie rozprawy Forberga, dlatego zdecydował się jednocześnie zaprezentować własne, wcześniej już wyłożone stanowisko. Aluzje zawarte w początkowych akapitach rozprawki Fichtego z pewnością odnoszą się do prowadzonych od dawna wykładów oraz przygotowywanych pism poświęconych Teorii wiedzy (Wissenschaftslehre) i Systemowi teorii moralności (Das System der Sittenlehre) ${ }^{11}$. Stosunek Fichtego do religii jest bez wątpienia konsekwencją transcendentalnego punktu widzenia Teorii wiedzy ${ }^{12}$. Uważa on przy tym, że skoro sprzeciwu nie budziły poglądy wcześniej wygłaszane, nie ma podstaw, by na krytykę zasługiwała ich obecna prezentacja. Ten sposób obrony został wybrany nieprzypadkowo, skoro Forberg uważał swój pogląd jedynie za rozwinięcie stanowiska Fichtego, sformułowanego w jego wczesnej pracy poświęconej krytyce objawiania. W zamierzeniu rozprawka Fichtego była więc próbą zapobieżenia opacznym interpretacjom jego własnej filozofii, paradoksalnie jednak owe dezinterpretacje wywołała na szerszą skalę. Podobnie jak w przypadku Lessinga dla Fichtego niezamierzoną okazją do wyrażenia własnego stanowiska stała się polemika. Artykuł O podstawie naszej wiary $w$ boskie panowanie nad światem rozpoczyna szereg publikacji, w których filozof dał wyraz własnemu pojmowaniu religii. Rozprawka Fichtego nie odpowiada jednak na pytanie ani o istotę różnicy między religią a moralnością, ani o podstawę oryginalności stanowiska Fichtego względem Kantowskiej filozofii religii. Udzielenie odpowiedzi na te pytania musiałoby uwzględniać treść wszystkich pism wydanych pomiędzy 1798 a 1800 rokiem,

\footnotetext{
${ }^{10}$ Wyd. pol.: F.K. Forberg, Rozwój pojęcia religii, przeł. M. Jankowski oraz M. Anna Truś, „Filo-Sofija” 9 (2009), s. 209 i n.

${ }^{11}$ Emanuel Hirsch w tej kwestii odsyła czytelnika do tzw. manuskryptu halleńskiego.

E. Hirsch, Fichtes Religionsphilosophie im Rahmen der philosophischen Gesamtentwicklung Fichtes, Göttingen 1914, s. 59-60.

${ }^{12}$ Por. M. Wundt, Johann Gottlieb Fichte, Stuttgart 1927, s. 265.
} 
co znacznie wykraczałoby poza ramy niewielkiego szkicu ${ }^{13}$. Niniejsze opracowanie koncentruje się jedynie na głównej idei zaanonsowanej w artykule O podstawie naszej wiary $w$ boskie panowanie nad światem.

Fichte udzielając odpowiedzi na pytanie o podstawę naszej wiary w opatrzność ${ }^{14}$, wyraźnie nawiązuje do rezultatów filozofii Kanta - nie ma żadnych (spekulatywnych) dowodów boskiego panowania nad światem. Zakłada przy tym, że przesłanką w takim dowodzie miałoby być doświadczenie zmysłowego świata. Błędem krytykowanych dowodów było więc wywodzenie „tamtego" świata jako uzasadnienia i podstawy istnienia „tego" świata, choć tę rzekomą wiedzę czerpano z argumentacji odwrotnej, opartej na szczególnym doświadczeniu świata (porządku czy celowości). Porządek idei w boskim umyśle stwórcy świata - powiada Hume w Dialogach o religii naturalnej byłby równie niepojęty jak porządek rzeczy świata zmysłowego, dla którego szukamy poza nim samym podstawy. Nasze poznanie świata zmysłowego nie odsyła nas do niczego innego poza nim.

Kuno Fischer podkreśla, że prawdą fundamentalną w omawianej rozprawce jest prawomocność dedukcji religii na podstawach, jakich dostarcza Teoria wiedzy, to znaczy „dowodu, że wiara w boskie panowanie nad światem należy do Ja i że w jego określeniach posiada ona swoją podstawę" ${ }^{15}$. W tym sensie jest ona skutkiem określeń Ja, w jakim wiara w istnienie Boga - stwórcy świata, moralnego władcy i sędziego ludzkich uczynków - w systemie filozofii Kanta jako postulat wypływała z rozumu praktycznego. Przeciwstawienie Ja i świata to dla Fichtego porównywanie porządku moralnego i porządku przyrody, stanowiska transcendentalnego idealizmu i dogmatyzmu.

Brak wspomnianych dowodów spekulatywnych nie narusza jednak wiary człowieka w boskie panowanie - nie powinien jej naruszać, ponieważ wielu z tych, którzy nie wierzą, chętnie podawać będzie, jako uzasadnienie słuszności swego negatywnego przekonania, brak owych spekulatywnych dowodów.

[...] owa wiara wcale nie może zostać przedstawiona inaczej, aniżeli jako arbitralne postanowienie, które człowiek może podjąć bądź nie, zależnie od upodobania, [a zatem] jako wolna decyzja, by za prawdziwe uznać to, czego

\footnotetext{
${ }^{13}$ Kuno Fischer uważa, że najwięcej wątpliwości budzi przede wszystkim brak jasnego uzasadnienia tego, co czyniłoby wiarę moralną wiarą religijną, a porządek moralny - porządkiem boskim. Por. K. Fischer, Geschichte der neuern Philosophie, t. 5, Heidelberg 1869, s. 790.

${ }^{14}$ Termin „opatrzność” (Vorsehung) oraz „panowanie nad światem” (Weltregierung) utożsamia Fichte w Das System der Sittenlehre z 1812 roku (Fichtes nachgelassene Werke, t. 3, s. 84).

${ }^{15}$ K. Fischer, dz. cyt., s. 783.
} 
życzy sobie jego serce, ponieważ życzy ono sobie tego jako dopełnienia bądź rekompensaty niedostatecznie przekonującej racji dostarczonej przez nadzieję ${ }^{16}$.

Wiara została tu utożsamiona $\mathrm{z}$,arbitralnym przekonaniem” - znamy je choćby z Pierwszego wprowadzenia do „Teorii wiedzy”, z 1797 roku $^{17}$. Nawiązując do ustaleń Teorii Wiedzy, Fichte przypomina o dwóch podstawowych choć skrajnych - sposobach ujmowania świata zmysłowego. Pierwszy z nich - utożsamiany przez niego z przyrodoznawstwem - traktuje świat jako porządek zdeterminowany mechanicznie. Bez wątpienia można to stanowisko traktować jako rozwinięcie paradygmatu zapoczątkowanego przez Arystotelesa. Zgodnie z tym poglądem porządek bytu (rzeczy) należy traktować jako dany (absolutny), nieredukowalny do niczego innego punkt wyjścia naszego poznania. Istniejący świat jest ładem, który sam siebie uzasadnia, który wreszcie sam stanowi kamień probierczy wszelkiego ludzkiego poznania świata. W skrajnej postaci trzeba go uznać za całość i jedność scaloną przez nieznające wyjątku powszechne prawa. $Z$ tej perspektywy - z pewnością był to punkt widzenia, jaki przyjęli już starożytni atomiści - dla wyjaśnienia mechanizmu i jedności świata nie trzeba zakładać istnienia działającej celowo inteligencji (stwórcy świata), a zatem hipotezy, jaka leży u podstawy teistycznych wyobrażeń o stworzeniu świata. Dla konsekwentnie przeprowadzonego wyjaśnienia przyrody hipoteza teistyczna jest zbędna, a posługiwanie się nią do takiego celu należy uznać za błąd. W przedkrytycznej pracy Kanta znajdujemy klasyczny przykład tej argumentacji:

Jeśli budowa świata z całym jej porządkiem i pięknem - powie on - stanowi tylko efekt oddziaływania materii podlegkej powszechnym prawom swego ruchu, ślepa mechanika sił przyrody jest zaś w stanie wywieść z chaosu tak wspaniałe dzieła i osiągnąć tak wielką doskonałość, to dowodzenie istnienia Boga, opierające się na doznaniu piękna świata, traci wszelką moc. Przyroda okazuje się samowystarczalna, a zwierzchnictwo Boże - niepotrzebne. W epokę chrześcijaństwa znów wkracza Epikur, a nieuczciwa filozofia wypiera wiarę ofiarowującą owej epoce jasne, rozświetlające ją światło ${ }^{18}$.

${ }^{16}$ J.G. Fichte, Über den Grund unseres Glaubens an eine göttliche Weltregierung, [w:] Appellation an das Publikum... Dokumente zum Atheismusstreit um Fichte, Forberg, Niethammer. Jena 1798/99, hrsg. von Werner Röhr, Leipzig 1987, s. 12.

${ }_{17}$ Tenże, Pierwsze wprowadzenie do „Teorii wiedzy”, [w:] tegoż, Teoria wiedzy, przeł. M. J. Siemek, J. Garewicz, Warszawa 1996, s. 481 i n.

${ }^{18}$ I. Kant, Powszechna historia naturalna i teoria nieba, przeł. T. Kupś, R. Michalski, M. Żelazny, [w:] tegoż, Dzieła zebrane, t. 1, Toruń 2010, s. 201. 
Jedynie drugi - jak go określa Fichte - transcendentalny punkt widzenia usuwa trudności, do jakich prowadzi pierwszy sposób rozpatrywania świata zmysłowego. Jednak w artykule $O$ podstawie naszej wiary... Fichte pisze na ten temat lapidarnie, podkreślając jedynie, że świat zmysłowy staje się z tej perspektywy „odbiciem” naszej „,wewnętrznej aktywności”. Nasze Ja stanowi w tej sytuacji podstawę świata. Lakoniczność tej części rozważań być może wynika z przekonania, że zostały one bądź wyłożone w pismach poświęconych Teorii wiedzy czy w Systemie teorii moralności, bądź, o czym świadczą początkowe akapity rozprawki, mają zostać wyłożone później.

Jeśli świat zmysłowy rozpatrujemy z transcendentalnego punktu widzenia, wtedy znikają niemal wszystkie wymienione trudności. Nie ma wówczas żadnego istniejącego dla siebie świata, zaś we wszystkim, co spostrzegamy, spostrzegamy jedynie odbicie (Widerschein) naszej własnej wewnętrznej aktywności (Tätigkeit). O to zaś, co nie istnieje, zgodnie $\mathrm{z}$ tą podstawą, nie można pytać. Nie można niczego poza nią przyjąć, by je wyjaśnić.

Ze świata zmysłowego nie prowadzi żadna możliwa droga, która by pozwalała wznieść się do założenia jakiegoś moralnego porządku świata; jeśli tylko w sposób czysty pomyśli się świat zmysłowy, a nie tak, jak czynią to owi filozofowie, zakładając już niepostrzeżenie jego moralny porządek"19.

Sądzę, że w ustaleniu, co należałoby rozumieć przez „moralny porządek świata", pomocne będzie odniesienie do znaczenia, jakie wyrażeniu temu nadał Kant w Jedynej możliwej podstawie dowodu na istnienie Boga. „Moralną” określa Kant taką zależność rzeczy od Boga, w której Bóg jest podstawą rzeczy przez swoją wolę ${ }^{20}$. Wiara w taką moralną zależność zakłada, że Bóg jest bezpośrednim sprawcą porządku rzeczy. Kant uznaje to pojmowanie podstawy za charakterystyczne dla tradycyjnej wersji fizykoteologii i przeciwstawia je "niemoralnemu” rozumieniu takiej zależności, jakie propaguje we własnej udoskonalonej metodzie fizykoteologii, w której usuwa się bezpośredni związek pomiędzy istniejącą rzeczą a Boską wolą. Kant wychodzi bowiem ze skądinąd słusznego założenia, że „kierowanie się ku moralnym podstawom, to znaczy ku teleologicznemu objaśnieniu, znacznie utrudnia rozszerzenie filozoficznego poznania tam, gdzie jeszcze można przypuszczać, że fizyczne

${ }^{19}$ J.G. Fichte, Über den Grund, s. 14-15.

${ }^{20}$ I. Kant, Jedyna możliwa podstawa, s. 76. 
podstawy determinują następstwa przez powiązanie z koniecznymi ogólniejszymi prawami"21.

Tradycyjna fizykoteologia - Fichte doskonale uchwycił ten problem - jest $\mathrm{w}$ istocie doktryną eudajmonistyczną ${ }^{22}$. Eudajmonizm moralnej doktryny swych przeciwników Fichte rozumie jako konsekwencję traktowania Boga jako gwaranta szczęścia, jakiego człowiek sam nie jest w stanie osiągnąć, a które - zgodnie z ludzkim poczuciem sprawiedliwości - powinno zostać nam udzielone proporcjonalnie do moralności naszych czynów, będącej w naszej mocy (w najczystszej postaci koncepcję tę znajdujemy w Kantowskiej nauce o postulatach praktycznego rozumu). Eudajmonizm zakłada, że szczęście człowieka jest celem głównym, do którego nie tylko zmierza on samodzielnie, ale również, że jego osiągnięciu sprzyja zakładany bądź oczekiwany korzystny układ świata (ład i harmonia). Kant wyraźnie podkreślał, że nic nie wskazuje na to, byśmy mieli prawo do takiego optymistycznego uznania siebie za faworytów przyrody. Wizerunek Boga, jaki lansuje się w tak naiwnym obrazie porządku świata, jest całkowicie opaczny - stanowi mieszaninę antropomorfizmu, animizmu, fetyszyzmu itp. Krótko mówiąc, w najskrajniejszej postaci stoi on w wyraźnej sprzeczności z wizerunkiem moralnego władcy świata i, w istocie jak mało co, zasługuje na miano ateizmu. Między innymi do tych wątków nawiązał Fichte, broniąc się przed zarzutami o ateizm: „To, że nie chcę zgodzić się na ich bożki zamiast na prawdziwego Boga, jest tym, co nazywają oni ateizmem. Oto, za co mnie prześladowano" ${ }^{\prime 2}$. Przez ateizm Fichte rozumie nie tyle niewiarę w istnienie Boga - co Kant określał mianem ateizmu dogmatycznego - ale wiarę $\mathrm{w}$ pseudoboga, $\mathrm{w}$ sensie, $\mathrm{w}$ jakim pisze o tym już Epikur: „Bezbożny nie jest ten, kto odrzuca bogów czczonych przez tłum, lecz ten, kto podziela mniemanie tłumu o bogach" 24 .

Temu tradycyjnemu (w istocie eudajmonistycznemu) pojmowaniu uzasadnienia moralnego ładu świata Fichte przeciwstawia własne jego rozumienie, wyraźnie nawiązując przy tym do ustaleń Kantowskiej filozofii praktycznej. Skoro postępowanie człowieka jest moralne, gdy stanowi ono realizację maksym prawa dającego się traktować jak Boski nakaz, to ustanawianie porząd-

\footnotetext{
${ }^{21}$ Tamże, s. 97. W tym miejscu, być może po raz pierwszy, Kant wprowadza rozróżnienie pomiędzy konstytutywnym poznaniem intelektualnym oraz regulatywnym użyciem rozumu.

22 J G. Fichte, Appelation an das Publicum, [w:] tegoż, Sämmtliche Werke, t. 5, Berlin 1845-1846 , s. 217.

23 Tamże, s. 219.

${ }^{24}$ Diogenes Laertios, Żywoty i poglądy stynnych filozofów, przeł. K. Leśniak, Warszawa 1984, s. 644 .
} 
ku moralnego w świecie staje się zarazem ustanawianiem porządku Boskie$\mathrm{go}^{25}$. Wniosek taki jednak można formułować tylko z perspektywy rozumu praktycznego, dla Kanta miałby on wartość wyłącznie regulatywną. Fichte najwyraźniej przyjmuje to stanowisko, utożsamiając je z własnym „transcendentalnym punktem widzenia”. To, co dla Kanta jest rezultatem długiej drogi, mianowicie ustalenie, sformułowane dopiero w Krytyce władzy sądzenia, że na podstawie wiedzy o porządku świata zmysłowego nie można wznieść się do poznania Boga (do „moralnego porządku świata”), dla Fichtego jest punktem wyjścia: „Ład moralny jest tą boskością (das Göttliche), którą przyjmujemy. Powstaje ona dzięki sprawiedliwemu postępowaniu"26.

Problem relacji pomiędzy porządkiem moralnym a porządkiem przyrody Kant podejmował wielokrotnie, m.in. w rozważaniach dotyczących prawomocności tradycyjnej teodycei. Królewiecki filozof ostatecznie okazuje się zwolennikiem rozwiązania, w którym nie przyjmuje się za możliwe łączenie obu porządków w jedność, czego konsekwencją byłoby - jak czytamy już w pismach przedkrytycznych, zwłaszcza w późniejszej rozprawce $O$ daremności wszelkich filozoficznych prób $w$ teodycei - wyjaśnienie zdarzeń skądinąd naturalnych (jak trzęsienia ziemi) jako konsekwencji czynów ludzkich. $\mathrm{W}$ przeciwnym bowiem razie różnica pomiędzy moralnym a naturalnym porządkiem uległaby zatarciu. Zdarzenia naturalne (to, o czym wiemy) byłyby w tej sytuacji pośrednio konsekwencjami ludzkiego postępowania, bezpośrednio zaś skutkami Boskich postanowień (o czym nie wiemy).

Fichte nie uważa, że znajomość świata nadzmysłowego jest nam dostępna pośrednio na drodze tradycyjnej spekulacji (na przykład fizykoteologicznej). Sądzi raczej, że ja sam, jako istota wolna, jestem obywatelem porządku nadzmysłowego świata:

Uważam się za wolnego od wszelkich wpływów świata zmysłowego, absolutnie czynnego w sobie samym i przez siebie samego. A zatem [uważam się], za moc wyższą od wszystkiego, co zmysłowe. Wolność ta nie jest jednak nieokreślona. Ona ma swój cel. Jednakże nie uzyskuje go ona z zewnątrz, lecz raczej sama ustanawia go dzięki samej sobie. Ja sam i mój konieczny cel są tym, co nadzmysłowe.

Nie mogę wątpić w tę wolność i takie jej określenie, nie niwecząc zarazem samego siebie.

${ }^{25}$ Por. J.G. Fichte, Powołanie człowieka, przeł. A. Zieleńczyk, Kęty 2002, s. 92, 204, 107.

${ }^{26}$ Tenże, Über den Grund, s. 18. 
Nie mogę wątpić, powiadam, nie mogę nawet pomyśleć takiej możliwości, że jest tak, iż ów wewnętrzny głos zwodzi, i że dopiero przez coś innego musi on zostać uwiarygodniony i uzasadniony. Nie mogę o tym zatem w ogóle dalej rozmyślać, objaśniać i wyjaśniać. Ów głos (Ausspruch) jest absolutnie pozytywny i kategoryczny ${ }^{27}$.

Nieomylność moralnego usposobienia jest tu aksjomatem - jej pierwowzór znajdujemy już w pracach Kanta. Przywołajmy pewien ciekawy przykład owej nieomylności, jakiego dostarcza oryginalna interpretacja ofiarowania Izaaka zamieszczona w Sporze fakultetów - rozprawie, która ukazała się w roku publikacji omawianego artykułu Fichtego. Kant przypisuje Abrahamowi następujące słowa: „»To, że nie powinienem zabić mego dobrego syna, jest pewne; że jednak ty, który zdajesz mi się objawiać jako Bóg jesteś Bogiem, tego nie jestem pewien i pewien być nie mogęu, nawet jeśliby ów głos rozbrzmiewał $\mathrm{z}$ (widzialnego) nieba" ${ }^{28}$. Słów tych nie znajdziemy w Biblii, są one fikcją, którą Kant zaczerpnął z poematu Wielanda Die Prüfung Abraham. Słowa przypisane przez Kanta Abrahamowi w poemacie Wielanda wypowiada jednak Eleazar - sługa Abrahama. Przesłanie tekstu Kanta jest jednak czytelne. Wypowiedź Abrahama przeciwstawia sobie dwa rodzaje pewności. Pierwsza - niewątpliwa - wypływa z rozumu praktycznego („To, że nie powinien zabić mego dobrego syna, jest pewne") oraz druga - z rozumu teoretycznego - to w istocie wątpliwość w możliwość rozszerzenia poznania o przedmioty nadzmysłowe („że jednak ty, który zdajesz mi się objawiać jako Bóg jesteś Bogiem, tego nie jestem pewien i pewien być nie mogę"). Wniosek, jaki nasuwa się na tej podstawie, jest również kluczowy dla oceny prawomocności obranej przez Kanta linii interpretacji Biblii - wykładnia oparta na zasadach moralnych zawsze będzie bezbłędna. Wydaje się, że również Fichte w podobny sposób rozumie relację pomiędzy porządkiem poznania a porządkiem moralnym:

Przekonanie o naszym moralnym powołaniu samo więc już wypływa z moralnego usposobienia (Stimmung) i jest wiarą. Dlatego słusznie powiada się, że podstawą wszelkiej pewności jest wiara. - Musi tak być, ponieważ moralność, na tyle, na ile jest ona pewna, może ostatecznie zostać ukonstytuowana tylko dzięki samej sobie, nie zaś dzięki jakiemuś logicznemu przymusowi argumentacji ${ }^{29}$.

\footnotetext{
27 Tamże, s. 15.

${ }^{28}$ I. Kant, Spór fakultetów, przeł. M. Żelazny, Toruń 2003, s. 118.

${ }^{29}$ J.G. Fichte, Über den Grund, s. 15-16.
} 
Pewność moralna - w terminologii Fichtego: wiara w porządek moralny - jest pierwotna względem pewności rozumu teoretycznego ${ }^{30}$. Stąd też wynika priorytet powinności przed możliwością. Etyka normatywna nie może być wyprowadzona $\mathrm{z}$ ludzkiego postępowania - postępowaniu temu dostarcza raczej pierwowzoru. Fichte jednak ma na myśli coś więcej. Sprzeciwia się mianowicie wszelkim próbom spekulowania o konsekwencjach własnego postępowania, by dzięki temu podejmować takie decyzje, które mają skutkować przewidywanymi z góry i zarazem pożądanymi rezultatami. Nie chodzi bowiem o to, że przewidywanie takie może być błędne, ale o to, że może ono w poczuciu realizacji w jakiejś odległej przyszłości domniemanych dóbr dopuszczać zło w obecnie podejmowanych czynach.

Domniemany podział na świat zmysłowy i nadzmysłowy zanika, jeśli w swej autonomii podejmuję działanie jako istota od świata niezależna, a działając w taki sposób, tworzę świat - obierając maksymy woli zgodnie z formą najwyższej zasady moralnego prawa „ucieleśniam” - powiada Fichte - „materię mego obowiązku” ${ }^{31}$. W istocie tworzę więc świat, jaki nie istnieje, lecz świat wypływający z nadzmysłowego porządku moralnego prawa - w tym sensie realizuję porządek nadzmysłowy. Świat jako scena mojego działania staje się porządkiem moralnym. Fichte dokonuje w ten sposób utożsamienia dwóch porządków rozdzielonych jeszcze u Kanta - porządku wolności wewnętrznej i wolności zewnętrznej.

Teologia moralna w jakimś sensie stanowiła dla Kanta zwieńczenie jego własnych prób formułowania alternatywy dla teologii spekulatywnej. Kant uznał ostatecznie, że podstawą religii jest moralny ład praktycznego prawa zarazem jedyne źródło pewności nadzmysłowego porządku świata. Porządek świata zjawiskowego, jak sugerują pewne fragmenty Krytyki praktycznego rozumu, moglibyśmy rozpatrywać jako pole realizacji nadzmysłowego ładu prawa moralnego, który dla tego pierwszego mógłby stanowić pierwowzór:

[...] przyrodę [nadzmysłową - T.K.] można by nazwać - przyrodą - prawzorem (natura archetypa), którą poznajemy jedynie w rozumie; zaś ten świat - przyrodą odwzorowaną (natura ectypa), ponieważ zawiera możliwy skutek idei przyrody nadzmysłowej jako wyznacznika woli. Faktycznie bowiem prawo moralne w swej idei przenosi nas w taką przyrodę, w której czysty rozum powołałby do życia najwyższe dobro, gdyby w parze z nim szła odpowiednia

${ }^{30}$ Por. tenże, Rückerinnerungen, Antworten, Fragen, [w:] Fichtes sämmtliche Werke, s. 345, $347,351$.

${ }^{31}$ Tenże, Über den Grund, s. 18. 
władza fizyczna; prawo to ponadto kieruje naszą wolę do nadania formy światu zmysłowemu jako całości istot rozumnych ${ }^{32}$.

Wyobrażenia o Bogu, a szerzej o porządku nadzmysłowym, nie sposób wyprowadzić na podstawie oglądu świata zjawisk, odwrotnie - porządek moralny dostarcza nam perspektywy do ujęcia przyrody jako części moralnego ładu świata. Relacja pomiędzy moralnym powołaniem człowieka a moralnym porządkiem świata jest tu sprawą kluczową. Zgodnie z duchem systemu filozofii Kanta moralne powołanie człowieka w pełni realizuje się $\mathrm{w}$ postępowaniu wypływającym $\mathrm{z}$ obowiązku. Postępowanie moralne jest przy tym wypełnieniem Boskiego planu: „Religia (traktowana subiektywnie) jest poznaniem wszystkich naszych obowiązków jako przykazań Bożych"33, jak głosi wielokrotnie przywoływana sentencja. Kant zakładał, że realizacja moralnego porządku świata jest wynikiem spełnienia moralnego powołania. Kantowskie określenie religii powinno być rozumiane jednak dokładnie jako określenie relacji pomiędzy tym, co może być przedmiotem wiary moralnej (nasze powołanie jako istot zdolnych do postępowania w sposób zdeterminowany obowiązkiem) oraz wiarą religijną, w odniesieniu do tego, co wykracza poza nasze możliwości. Wydaje się, że wiara w moralny porządek świata jest właśnie w taki sposób rozumiana przez Fichtego ${ }^{34}$. O ile jednak wiara moralna odnosiłaby się do mojego własnego powołania jako istoty moralnej, o tyle wiara w moralny porządek świata wykraczałaby poza niego, odnosząc się do konsekwencji mojego zgodnego z obowiązkiem postępowania w świecie, byłoby więc częścią całości świata, elementem urzeczywistnienia jego ogólnego planu. Na tym związku - celu mego postępowania we mnie i rozumowego celu poza mną - polega moralny porządek świata ${ }^{35}$. Wiara $\mathrm{w}$ ten porządek byłaby zarazem wiarą w tę jedność, a zatem w to, co - już w Krytyce praktycznego rozumu - zostało przedstawione jako coś, co ode mnie nie zależy.

W Religii w obrębie samego rozumu kontrowersje te odnoszą się do możliwości zrealizowania idei moralnej wspólnoty - jedności ludzi podlegających prawu moralnemu. Religijny charakter tej jedności Fichte uzasadnia etymologicznym znaczeniem łacińskiego słowa religio. We wczesnej rozprawie Ver-

\footnotetext{
${ }^{32}$ I. Kant, Krytyka praktycznego rozumu, przeł. B. Bornstein, Kęty 2002, s. 57.

33 Tenże, Religia w obrębie samego rozumu, przeł. A. Bobko, Kraków 1993, s. 188, 111; tenże, Krytyka praktycznego rozumu, s. 130; tenże, Krytyka władzy sądzenia, przeł. J. Gałecki, Warszawa 2004, s. 471.

${ }^{34}$ K. Fischer, dz. cyt., s. 791-792.

${ }^{35}$ Tamże, s. 791.
} 
such einer Kritik aller Offenbarung czytamy m.in.: „Teologia jest czystą nauką, martwą wiedzą, martwym poznaniem pozbawionym praktycznego wpływu. Religia ma być raczej zgodnie z dosłownym sensem (religio) czymś, co nas łączy, a nadto łączy nas silniej, niż byłoby to możliwe bez niej"36. Fichte odwołuje się w tym punkcie do etymologii Laktancjusza, chrześcijańskiego apologety z przełomu III i IV wieku, który w dziele zatytułowanym Divinae institutones religię określił jako ścisłe połączenie i moralny związek z Bogiem. Określenie to wywodził z łacińskiego czasownika religare, oznaczającego „wiązać”, „spajać". Nawiązanie do tej idei zjednoczenia można również dostrzegać na nieco innej płaszczyźnie, bliższej teorii postulatów praktycznego rozumu. W tej perspektywie jedność gwarantowana przez Boga odnosiłaby się do sprzeczności pomiędzy godnością człowieka jako istoty moralnej i szczęściem jako istoty naturalnej ${ }^{37}$. Bez wątpienia do tego literalnego znaczenia „religii” odnosi się Fichte, przy czym czyni to za pośrednictwem systemu filozoficzno-religijnego Kanta, w którym wszystkie obowiązki względem Boga w całości zostały przekształcone w obowiązki wobec człowieka. Zasadniczo jedność odniesień w świecie ludzkim wynika z jedności moralnego prawa, któremu podlega każda istota rozumna. Kontrowersje pojawiają się w późniejszych pismach Kanta, w których filozof podejmuje problem obecności w człowieku radykalnego pociągu do zła, w wyniku czego predyspozycje człowieka do dobra okazują się same w sobie niewystarczające, aby w pełni zrealizować ludzkie powołanie do dobra. Podstawowej zasady jednoczącej ludzi należy więc poszukiwać nie tylko poza obrębem możliwego doświadczenia, ale nawet poza źródłowymi predyspozycjami ludzkiej natury ${ }^{38}$ : „Nawet przy dobrej woli każdego pojedynczego człowieka, ze względu na brak jednoczącego pryncypium, ludzie byliby narzędziami zła, oddalając się przez ciągłe waśnie od wspólnego celu, jakim jest dobro" 39 .

To jednoczące pryncypium wolno nam nazwać Bogiem, a nawet uznać za założyciela moralnej wspólnoty. Czynimy tak jednak tylko dlatego, że źródło powstania moralnej wspólnoty pozostaje przed nami ukryte. Urzeczywistnienie tej idei daje się zrozumieć tylko przy założeniu istnienia Boga jako jej twórcy i prawodawcy ${ }^{40}$ : „Nadanie początku moralnemu ludowi Bożemu jest więc dziełem, którego nie można oczekiwać od człowieka, lecz tylko od

\footnotetext{
${ }^{36}$ J. G. Fichte, Versuch einer Kritik aller Offenbarung, [w:] Fichtes sämtliche Werke, s. 43.

${ }^{37}$ M. Wundt, dz. cyt., s. 259.

${ }^{38}$ A. Bobko, Kant i Schopenhauer, Rzeszów 1996, s. 201.

${ }^{39}$ I. Kant, Religia w obrębie, s. 124.

${ }^{40}$ A. Bobko, dz. cyt., s. 203.
} 
samego Boga"41. Przypisywana Bogu rola moralnego prawodawcy powinna być tutaj rozumiana w bardzo szczególny sposób, przede wszystkim tak, by uniknąć niebezpieczeństwa antropomorfizmu. Antropomorfizm oznaczałby w tym wypadku przypisywanie Bogu autorytetu, którym religia posługiwałaby się instrumentalnie dla egzekwowania narzucanych ludziom obowiązków. Bóg nie przemawia wprost, nadając prawa swemu ludowi, ale musi być założony jako ostateczna instancja, pierwszy poruszyciel porządku, w którym to, co może zostać do niego zaliczone, zostanie przypisane mu jako jego dzieło. Ta interpretacja jest całkowicie słuszna i uzasadniona na gruncie Religii..., nieco inaczej jednak przedstawia się w konfrontacji z treścią Opus postumum, wreszcie, wątpliwości może budzić towarzyszące jej założenie niewystarczalności siły ludzkiego rozumu do determinowania woli. Byłoby, jak sądzę, ze szkodą dla ducha filozofii Kanta przyjąć, że teza „etyka prowadzi nieodzownie do religii" ${ }^{2}$ oznacza zgodę na to, że siłą sprawczą gwarantującą obowiązywanie moralnego prawodawstwa może być tylko Bóg. Pogląd wyrażany w Religii... został zarzucony w późniejszych pismach. Kant był bowiem całkowicie świadomy paradoksów wynikających dla moralności z tego założenia. Opór przed określaniem owego ,jednoczącego pryncypium”, „fizycznej mocy” czy „siły sprawczej” za pomocą imienia judeochrześcijańskiego Boga wyraźnie widać już w pismach historiozoficznych, gdzie zamiast imienia Boga znajdujemy niekiedy wyraźnie antropomorfizowaną naturę czy opatrzność, jakby autor każdorazowo chciał dać do zrozumienia, że chodzi jedynie o oznaczenie nieznanego nam źródła uniwersalnej rozumności.

Przypisywane następcom Kanta (Fichtemu, a zwłaszcza Heglowi) przekonanie, że chrześcijaństwo dostarczyło zasad, na jakich mogła oprzeć się struktura nowoczesnego społeczeństwa obywatelskiego, nie daje się utrzymać (chociaż jest to jedna z konsekwencji przewidzianych przez Kanta). Kant wyraźnie oddziela etyczny porządek religii (porządek czystego rozumu praktycznego) oraz polityczny porządek instytucji społecznych, w szczególny sposób podkreśla ich wzajemną nieprzekładalność, a jednocześnie protestuje przeciwko uproszczeniom formułowanym w obrębie kościelnych wyznań. Problem dostrzeżony przez Kanta w Religii... stał się również kluczowym wątkiem Fichteańskich pism filozoficzno-religijnych.

Mędrkowanie o przyczynie świata popada nieuchronnie w antropomorfizm, przez to zaś sprzyja porównywaniu Boga do człowieka. Przy tak rozu-

\footnotetext{
${ }^{41}$ I. Kant, Religia w obrębie, s. 128.

${ }^{42}$ Tamże, s. 26.
} 
mianym Bogu porządek moralny świata można byłoby równie dobrze wyprowadzać bezpośrednio z nas samych (skoro my sami jesteśmy pierwowzorem dla utworzonego pojęcia Boga jako pierwszej przyczyny). Tymczasem spekulatywne dowody, nawet tzw. argument moralny, w sposób sztuczny rozdzielają to, co stanowi jedność nierozerwalną. Boskość nie jest tym, co zaświatowe. Moralny porządek jest samym Bogiem - jedynym, jaki znamy ${ }^{43}$. Oznacza to jednak również, że moralny porządek nie jest i być nie może przez nas traktowany jako nasze własne dzieło. Nie jest wytworem skończonej istoty moralnej, nie jest czymś wytworzonym ani niczym z zewnątrz zarządzonym. Nie ma Fichte przez to na myśli tego, że nie mamy w nim swego udziału, chodzi raczej o to, że nie może być uznany za coś stałego i gotowego (w tym sensie za coś martwego). Moralny porządek świata jest żywym, działającym porządkiem, nie jest - Fichte posługuje się terminologią łacińską - ordo ordinatus, ale ordo ordinans ${ }^{44}$. Wątki te inicjują już jednak idee obecne w późniejszych pracach Fichtego, znanych polskiemu czytelnikowi z Powołania człowieka ${ }^{45}$, a zatem $\mathrm{z}$ rozprawy, która zamyka okres sporów o domniemany ateizm Fichtego.

\section{Abstract \\ Johann Gottlieb Fichte's justification of belief in the moral order of the world}

Answering the question about the grounds of our belief in the Providence Fichte clearly refers to the results of Kantian philosophy, according to which there are no (speculative) arguments of divine governance over the world. For the author of Theory of Knowledge the premise in such an argument should be the experience of sensual world. The error of the criticized arguments is deriving "the other" world as the justification and ground of the existence of "this" world, though this apparent knowledge was itself derived from a reverse argumentation, based on a peculiar experience of the world (of its order or beauty). Johann Gottlieb Fichte's essay Über den Grund unseres Glaubens an eine göttliche Weltregierung, which was designed as a polemic with Friedrich Karl Forberg, was the reason for the Fichte's atheism controversy.

\footnotetext{
${ }^{43}$ K. Fischer, dz. cyt., s. 785-786.

${ }^{44}$ J.G. Fichte, Aus einem Privatschreiben, [w:] Fichtes sämtliche Werke, s. 381-382.

${ }^{45}$ Por. tenże, Powołanie człowieka, s. 92 i n.
} 